\title{
Glazbene preferencije učenika prema durskim i molskim skladbama
}

\author{
Daniela Petrušić* \\ dpetrusic@ffst.hr \\ https://orcid.org/0000-0002-2302-8917 \\ Lidija Brkan ** \\ lidija.brkan@gmail.com \\ https://orcid.org/0000-0002-9661-305X
}

https://doi.org/10.31192/np.19.1.10

UDK: 78:303.62-057.87

37.016:78

Izvorni znanstveni rad / Original scientific paper

Primljeno: 18. rujna 2020.

Prihvaćeno: 14. listopada 2020.

Cilj ovoga istraživanja bio je ispitati učeničke preferencije klasične glazbe, učeničke preferencije klasične glazbe u duru i u molu te utjecaj poznatosti na učeničke preferencije klasične glazbe. Istraživanje je provedeno u veljači 2019. godine. U okviru istraživanja primijenjen je upitnik općih podataka te skala procjene za ispitivanje preferencija glazbenih ulomaka na uzorku od 250 učenika drugih, trećih, sedmih i osmih razreda osnovne škole. Rezultati potvrđuju da su dob i spol značajni prediktori preferencija klasične glazbe. Djevojčice u odnosu na dječake te mladi učenici u odnosu na starije učenike preferiraju klasičnu glazbu. Dobiveni rezultati ukazuju na to da učenici preferiraju klasičnu glazbu u molu, nego u duru. Konačno, poznavanje glazbe pokazalo se značajnim faktorom koji utječe na glazbene preferencije učenika, što je u skladu s brojnim dosadašnjim istraživanjima.

Ključne riječi: dur, glazbene preferencije, klasična glazba, mol, nastava glazbe.

\section{Uvod}

Glazba je umjetnost koja poboljšava kvalitetu ljudskog života jer utječe na razvoj vrlina, pomaže intelektualnom i duhovnom sazrijevanju pojedinca te svakodnevicu čini kvalitetnijom i sadržajnijom. Bavljenje glazbom ima veliku ulogu u dječjem razvoju stoga je od iznimne važnosti da glazbeno obrazovanje bude otvoreno prema razvoju i primjeni inovativnih obrazovnih ideja. Doka-

\footnotetext{
* Daniela Petrušić, prof. glazbeno teorijskih predmeta, asistent, Filozofski fakultet Sveučilišta u Splitu, Odsjek za rani i predškolski odgoj i obrazovanje, Poljička cesta 35, HR-21000 Split.

"*:Lidija Brkan, mag. prim. educ., Dinka Stambaka 7, HR-21260 Imotski.
} 
zano je da glazba poboljšava učenje, razvija pamćenje, utječe na bolju koncentraciju, veću disciplinu te poboljšava opuštanje i motivaciju učenika. Također, glazba omogućava učenicima da razvijaju svoje vještine, da usvajaju i razmjenjuju znanja, kao i da njeguju iskrenu ljubav prema učenju. ${ }^{1}$

Glazbeni jezik je kompleksan sustav unutar kojega na više razina i s različitim intenzitetom djeluju raznovrsne odrednice koje direktno utječu na formiranje glazbenih preferencija i glazbenog ukusa, a koje svako relevantno istraživanje mora uzeti u obzir i što točnije definirati. Glazbeni ukus jest ukupnost preferencija pojedinca prema nekom stilu glazbe i on podrazumijeva trajne dispozicije te ustaljeno, dugoročno ponašanje i vrednovanje glazbenog djela. $\mathrm{Na}$ formiranje glazbenog ukusa kod djeteta od najranije dobi najviše utječe okolina, roditelji, vršnjaci i masovni mediji. Prije polaska u školu djeca ne znaju aktivno slušati ni vrednovati glazbu, već slušaju ono što im je dostupno ili nametnuto, uglavnom putem medija. Stoga je od iznimne važnosti da se na nastavi Glazbene kulture razvija kritički i estetski ukus za kvalitetnu glazbu tako da se učenici upoznaju s različitim glazbenim pojmovima i stilovima glazbe upravo aktivnim slušanjem te glazbe. Aktivno slušanje glazbe podrazumijeva da se učenicima neposredno prije slušanja glazbenog djela zadaju pitanja glazbene prirode koja trebaju biti primjerena njihovim perceptivnim sposobnostima.

»To je slušanje koje se provodi s namjerom da se glazba upozna i doživi kao umjetnost i da ona sama, umjetnički proživljena, izvrši određene umjetničke učinke, uspostavljajući i razvijajući umjetnički glazbeni ukus kod učenika.«²

Glazbene preferencije možemo definirati kao kratkoročne procjene sviđanja koje su podložne čestim promjenama zbog brojnih čimbenika koji na njih stalno utječu. Na formiranje glazbenih preferencija utječu: karakteristike glazbe (tempo, ritam, visina, harmonija, dinamika, tonalitet, poznatost glazbe, glazbeni stilovi, izvođački medij), ponavljanje i poznatost glazbe, kognitivni čimbenici (komunikacija, zadovoljavanje potreba, izražavanje osobnih vrijednosti ili identiteta, kontaktiranje s drugim ljudima, stjecanje informacija, autorefleksija), emocionalni čimbenici (regulacija raspoloženja, evociranje emocija, opuštanje), kulturni i društveni čimbenici (izražavanje identiteta, osobnosti i vrijednosti drugih ljudi i društva, supkulture), fiziološka pobuđenost (promjene otkucaja srca ili krvnog tlaka) i osobine slušatelja (dob, spol, socioekonomski status, strategije slušanja, glazbeno iskustvo, osobnost, vršnjaci). ${ }^{3}$ Od iznimne je važnosti poznavanje čimbenika koji utječu na formiranje glazbenih preferencija radi razumijevanja osobnosti pojedinca i odabira glazbenih sadržaja koji

\footnotetext{
${ }^{1}$ Usp. Nina JACKSON, Mala knjiga glazbe za učionicu, Lekenik, Ostvarenje, 2009, 2.

2 Snježana DOBROTA, Gordana ĆURKOVIĆ, Glazbene preferencije djece mlađe školske dobi, Život i škola, 15-16 (2006) 1-2, 105-113, 107.

${ }^{3}$ Usp. Snježana DOBROTA, Ina REIĆ ERCEGOVAC, Zašto volimo ono što slušamo? Glazbenopedagoški i psihologijski aspekti glazbenih preferencija, Split, Filozofski fakultet Sveučilišta u Splitu, 2016, 13-31.
} 
su primjereni i zanimljivi dobi učenika. »Na taj način glazbena nastava postaje značajan čimbenik formiranja glazbenih preferencija učenika te razvijanja ljubavi prema glazbi i trajne potrebe za glazbenim iskustvima. ${ }^{4}$

Različiti teorijski modeli glazbenih preferencija povezuju čimbenike koji utječu na njihovo formiranje kod pojedinca. Interaktivna teorija glazbenih preferencija ${ }^{5}$ prikazuje hijerarhiju varijabli koje utječu na glazbene preferencije pojedinca. Model sadrži osam razina kojima slušatelj obrađuje ulaznu informaciju, pri čemu najniže razine uključuju podražaj te kulturne i osobne čimbenike koji utječu na kretanje informacije do mjesta na kojemu se odvija njezina obrada. Varijable na tim razinama nazivaju se varijablama utjecaja, a varijable na višim razinama su odgovor na varijable utjecaja. ${ }^{6}$ Recipročni model reakcije na $g l a z b u^{7}$ usmjerava se prema trima glavnim utjecajima na glazbene preferencije, i to na glazbu, slušatelja te situacije i kontekste. Uzimajući u obzir djelovanje navedenih utjecaja, autori modela dolaze do četiriju njegovih komponenti, a to su glazba, situacije i konteksti, reakcija na glazbu i slušatelj. ${ }^{8}$ Za razliku od LeBlancova modela, $u$ kojemu su socijalna interakcija i emocije na rubu, u recipročnom modelu reakcije na glazbu oni zauzimaju značajno mjesto. I, konačno, revidirani recipročni model reakcije na glazbu ${ }^{9}$ polazi od ideje da mašta čini bit kreativne percepcije glazbe. Čimbenici koji se odnose na glazbu i na situacije i kontekste ostali su nepromijenjeni, dok je varijabla slušatelj nadopunjena varijablama skladatelj/improvizator/izvođač. Umjesto varijable odgovor uključuje se mašta koja čini temelj modela i koja inkorporira percepciju i produkciju. ${ }^{10}$

Najveći broj istraživanja ${ }^{11}$ čimbenika koji utječu na glazbene preferencije odnosi se na osobine glazbe i osobine slušatelja. ${ }^{12}$ Što se tiče osobina slušate-

${ }^{4}$ Isto, 94.

${ }^{5}$ Usp. Albert LEBLANC, An interactive theory of music preference, Journal of Music Therapy, 29 (1982) 28-45.

${ }^{6}$ Usp. Dobrota, Reić Ercegovac, Zašto volimo ono što slušamo?..., 43-44.

${ }^{7}$ Usp. David J. HARGREAVES, Dorothy MIELL, Raymond A. R. MCDONALD, How do people communicate using music?, u: Dorothy MIELL, Raymond A. R. McDONALD, David J. HARGREAVES (ur.), Musical communication, Oxford, Oxford University Press, 2005, 1-25.

${ }^{8}$ Usp. Dobrota, Reić Ercegovac, Zašto volimo ono što slušamo..., 45-49.

${ }^{9}$ Usp. David J. HARGREAVES, Jonathan James HARGREAVES, Adrian C. NORTH, Imagination and creativity in music listening, u: David J. HARGREAVES, Dorothy MIELL, Raymond A. R. MCDONALD (ur.), Musical Imaginations. Multidisciplinary Perspectives on Creativity, Performance and Perception, Oxford, Oxford University Press, 2012, 156-172.

${ }^{10}$ Usp. Dobrota, Reić Ercegovac, Zašto volimo ono što slušamo?..., 49-53.

${ }^{11}$ Usp. Snježana DOBROTA, Ina REIĆ ERCEGOVAC, Music preferences with regard to music education, informal influences and familiarity of music, British Journal of Music Education, 34 (2017) 1, 41-55.

${ }^{12}$ Usp. Katarina HABE, Snježana DOBROTA, Ina REIĆ ERCEGOVAC, The structure of musical preferences of youth. Cross-cultural perspective, Musicological Annual, 54 (2018) 1, 141-156; Peter G. RENTFROW, Samuel D. GOSLING, The do re mi's of everyday life. The structure and personality correlates of music preferences, Journal of personality and social psychology, 84 (2003) 6, 1236-1256. 
lja, brojna istraživanja $\mathrm{a}^{13}$ bavila su se utjecajem socioekonomskog statusa, dobi, spola, glazbene poduke, glazbenih sposobnosti te osobina ličnosti slušatelja na formiranje njegovih glazbenih preferencija. ${ }^{14}$ Od glazbeno-izražajnih sastavnica koje su povezane s glazbenim preferencijama slušatelja, najveći broj istraživanja bavio se tempom, dinamikom, tonalitetom, izvođačkim medijem, glazbenim stilom i poznatosti glazbe. ${ }^{15}$

Tonalitet je jedan od važnih čimbenika koji utječe na glazbene preferencije slušatelja. Istraživanje provedeno na trideset osmero djece, $u$ dobi tri do dvanaest godina, ispitivalo je preferencije djece prema durskim i molskim skladbama. ${ }^{16} \mathrm{U}$ istraživanju su korištene četiri vrste glazbenih odlomaka: melodije $\mathrm{u}$ duru s harmonijskom pratnjom, melodije u molu s harmonijskom pratnjom, neharmonizirane melodije $u$ duru i neharmonizirane melodije u molu. Za svaki odslušani glazbeni ulomak djeca su svoje emocije izražavali uz pomoć četiri emotikona: dva su predstavljala pozitivne emocije (sreću i zadovoljstvo) a dva negativne (tugu i ljutnju). Melodije u duru većina djece je vezala uz pozitivne emocije, dok su melodije u molu imale pretežno negativnu emocionalnu konotaciju. Tome je pridonijela i harmonijska pratnja pjesme, tako da su neharmonizrane melodije u duru imale više pozitivnih emocionalnih reakcija djece, dok su melodije u molu upravo harmonizacijom povećale učestalost povezivanja molskog tonaliteta s negativnim emocijama.

Slični rezultati dobiveni su u ispitivanju povezanosti tonaliteta s emocionalnom reakcijom djece podijeljene na dvije skupine, od tri do četiri i od sedam do osam godina. ${ }^{17}$ Rezultati pokazuju da djeca u dobi od sedam do osam godina, kao i odrasli, uglavnom povezuju mol s tužnim raspoloženjem, a dur sa sretnim, dok djeca uzrasta tri do četiri godine nisu pokazala značajnu povezanost između tonaliteta i emocionalnog odgovora. Također, značajan faktor u emocionalnom doživljaju durskih i molskih skladbi pokazala je harmonijska pratnja pjesme koja pridonosi povećanju učestalosti sretnog raspoloženja.

Na dinamičan odnos glazbenih preferencija i čimbenika koji utječu na njihovo formiranje značajno utječe i kultura iz koje slušatelj potječe i u kojoj živi. Stoga su Balkwill i Thompson proveli istraživanje u interkulturalnom kontek-

${ }^{13}$ Usp. Ina REIĆ ERCEGOVAC, Snježana DOBROTA, Dubravka KUŠČEVIĆ, Relationship between music and visual art preferences and some personality traits, Empirical Studies of the Arts, 33 (2015) 2, 207-227.

${ }^{14}$ Usp. Peter G. RENTFROW, Samuel D. GOSLING, Message in a ballad. The role of music preferences in interpersonal perception, Psychological Science, 17 (2006) 3, 236-242.

${ }^{15}$ Usp. Snježana DOBROTA, Ina REIĆ ERCEGOVAC, The relationship between music preferences of different mode and tempo and personality traits - implications for music pedagogy, Music Education Research, 17 (2015) 2, 234-247.

${ }^{16}$ Usp. Marianna Pinchot KASTNER, Robert G. CROWDER, Perception of the Major/Minor Distinction. IV. Emotional Connotations in Young Children, Music Perception, 8 (1990) 2, 189201.

${ }^{17}$ Usp. Andrew H. GREGORY, Lisa WORRALL, Ann SARGE, The development of emotional responses to music in young children, Motivation and Emotion, 20 (1996) 4, 341-348. 
stu. ${ }^{18}$ Njihovo istraživanje je provedeno na trideset ispitanika iz zapadne civilizacije koji su slušali dvanaest glazbenih ulomaka iz Sjeverne Indije. Ispitanici su u tim glazbenim ulomcima procjenjivali stupanj radosti, tuge, bijesa i mira te njihov tempo, ritamsku i melodijsku složenost i opseg melodije. Pokazalo se da su ispitanici bili jako osjetljivi na razlikovanje emocija sreće, tuge i bijesa, što je bilo značajno povezano s prosudbama psihofizičkih varijabli glazbenih ulomaka, a u nekim slučajevima i s bojom instrumenta. Dobiveni rezultati pokazali su da ispitanici imaju iznimnu osjetljivost za razlikovanje emocija izraženih glazbom u nepoznatom tonalnom sustavu.

Istraživane su i reakcije dojenčadi od tri, pet, sedam i devet mjeseci i njihove sposobnosti razlikovanja glazbenih ulomaka koje su predškolska djeca i odrasli definirali kao sretne ili tužne. ${ }^{19}$ Pokus je obuhvatio postupak privikavanja dojenčadi na tri skladbe istog raspoloženja, a potom im je pušten ulomak suprotne emotivne konotacije. Dojenčad od devet mjeseci razlikovala je glazbene ulomke ocijenjene kao afektivno različite, oni od pet i sedam mjeseci razlikovali su sretne i tužne ulomke samo kada su bili naviknuti na tužne, ali ne i kad su bili naviknuti na vesele ulomke, dok dojenčad od tri mjeseca nije pokazala nikakvu sposobnost razlikovanja tužnih i sretnih glazbenih ulomaka.

Dinamičan odnos glazbenih preferencija i čimbenika koji utječu na glazbene preferencije te glazbeni ukus kao rezultat tog dinamičkog odnosa, odvija se kontekstualno, ovisno o okruženju razvoja samospoznaje pojedinca, kulture koja ga oblikuje i umjetnosti koju konzumira. Oslanjajući se na spomenuta istraživanja koja su nam poslužila kao okvir pri formuliranju četiri radne hipoteze, u ovom radu ispitat ćemo učeničke preferencije klasične glazbe u duru i molu te utjecaj poznavanja glazbe na njihove glazbene preferencije.

\section{Tema istraživanja: Glazbene preferencije učenika prema klasičnoj glazbi u duru i u molu}

Cilj istraživanja je ispitati učeničke preferencije klasične glazbe, učeničke preferencije klasične glazbe u duru i u molu te utjecaj poznatosti na učeničke preferencije klasične glazbe. U skladu s ciljem postavljeni su sljedeći problemi istraživanja:

1. Ispitati postoji li utjecaj dobi na učeničke preferencije klasične glazbe.

2. Ispitati postoji li utjecaj spola na učeničke preferencije klasične glazbe.

\footnotetext{
${ }^{18}$ Usp. Laura-Lee BALKWILL, William Forde THOMPSON, A Cross-Cultural Investigation of the Perception of Emotion in Music. Psychophysical and Cultural Cues, Music Perception: An Interdisciplinary Journal, 17 (1999) 1, 43-64.

${ }^{19}$ Usp. Ross FLOM, Douglas A. GENTILE, Anne D. PICK, Infants' discrimination of happy and sad music, Infant Behavior and Development, 31 (2008) 4, 716-728.
} 
3. Ispitati postoji li utjecaj tonaliteta na učeničke preferencije klasične glazbe.

4. Ispitati odnos između poznavanja klasične glazbe i učeničkih preferencija takve glazbe.

$\mathrm{Na}$ temelju definiranog cilja i problema istraživanja postavljene su sljedeće hipoteze:

H1: Mlađi učenici, u odnosu na starije učenike, više preferiraju klasičnu glazbu.

H2: Učenice, u odnosu na učenike, više preferiraju klasičnu glazbu.

H3: Učenici više preferiraju klasičnu glazbu u duru, nego u molu.

H4: Učenici više preferiraju poznatu klasičnu glazbu, u odnosu na klasičnu glazba koja im nije poznata.

\section{Metoda}

\subsection{Sudionici}

Ispitivanje je provedeno u Splitu (OŠ Manuš) u veljači 2019. godine na uzorku od 250 učenika ( $\check{Z}=116, M=134)$ : drugog $(N=68)$, trećeg $(N=72)$, sedmog $(\mathrm{N}=58)$ i osmog razreda $(\mathrm{N}=52)$ osnovne škole (tablica 4). Učenici drugog i trećeg razreda u analizi podataka grupirani su u skupinu mlađi učenici, a učenici sedmog i osmog razreda u skupinu stariji učenici.

Tablica 1. Struktura uzorka $(\mathrm{N}=250)$

\begin{tabular}{|c|c|c|c|}
\hline SPOL & N & RAZRED & N \\
\hline \multirow{2}{*}{ M } & \multirow{2}{*}{134} & 2 & 68 \\
\cline { 3 - 4 } & & 3 & 72 \\
\hline \multirow{2}{*}{$\check{Z}$} & \multirow{2}{*}{116} & 7 & 58 \\
\cline { 3 - 4 } & & 8 & 52 \\
\hline Ukupno & \multicolumn{3}{|c|}{250} \\
\hline
\end{tabular}

\subsection{Instrument i postupak ispitivanja}

U istraživanju je korišten glazbeni nosač zvuka na kojemu se nalazi dvanaest glazbenih ulomaka klasične glazbe, od čega je šest u duru, a šest u molu, svaki u trajanju od oko jedne minute (tablica 5). Raspodjela učeničkih preferencija klasične glazbe u duru i u molu značajno se razlikuju od normalne distribucije, stoga će se u daljnjim analizama primijeniti postupci neparametrijske statistike. 
Tablica 2. Psihometrijske značajke podskala Preferencije klasične glazbe u duru i u molu

\begin{tabular}{|c|c|c|}
\hline & DUR & MOL \\
\hline & R. Schumann: Radostan seljak & J. S. Bach: 2. suita u h-molu, Badinerie \\
\hline & $\begin{array}{l}\text { P. I. Čajkovski: Koračnica iz baleta } \\
\text { Orašar }\end{array}$ & R. Schumann: Divlji jahač \\
\hline & J. Strauss: Pizzicato polka & L. van Beethoven: $Z a$ Elizu \\
\hline & $\begin{array}{l}\text { W. A. Mozart: Klavirska sonata u } \\
\text { A-duru, KV 331, 3. st., AllaTurca }\end{array}$ & J. S. Bach: Toccata u d-molu, BWV 565 \\
\hline & G. Rossini: Wilhelm Tell, uvertira & $\begin{array}{l}\text { J. Brahms: Madarski ples u g-molu, } \\
\text { br. } 5\end{array}$ \\
\hline & E. Grieg: Peer Gynt, Jutro & $\begin{array}{l}\text { P. I. Čajkovski: Koncert za klavir } i \\
\text { orkestar br. } 1 \text { u b-molu, op. } 23,1 \text {. } \\
\text { stavak }\end{array}$ \\
\hline Cronbach $\alpha$ & 0,81 & 0,80 \\
\hline $\mathrm{M}(\mathrm{sd})$ & $24,87(4,89)$ & $25,32(4,93)$ \\
\hline Raspon & $6-30$ & $6-30$ \\
\hline $\begin{array}{l}\text { prosječna } \\
\text { r među } \\
\text { česticama }\end{array}$ & 0,42 & 0,44 \\
\hline $\mathrm{K}-\mathrm{S} \mathrm{d}$ & $0,17 \mathrm{p}<0,01$ & $0,17 \mathrm{p}<0,01$ \\
\hline
\end{tabular}

Glazbeni nosač zvuka konstruiran je isključivo za potrebe ovog istraživanja, a kriterij izbora glazbenih ulomaka bile su postavljene hipoteze. Za potrebe istraživanja konstruiran je upitnik koji sadrži dva dijela. U prvom dijelu nalaze se pitanja koja se odnose na sociodemografska obilježja učenika (spol i dob). Drugi dio upitnika je ljestvica procjene sviđanja glazbe. Zadatak sudionika je bio da nakon odslušanog glazbenog ulomka na ljestvici Likertova tipa, zaokruživanjem brojeva od jedan do pet $(1=$ uopće mi se ne sviđa; $2=$ ne sviđa mi se; $3=$ osrednje mi se sviđa; $4=$ sviđa mi se; $5=$ jako mi se sviđa), procijene stupanj sviđanja pojedinog glazbenog ulomka te da procijene je li im glazbeni ulomak poznat od prije ili nije. Sudionicima je objašnjena svrha provođenja istraživanja, zajamčena im je anonimnost te su zamoljeni da iskreno i precizno odgovaraju na pitanja.

\section{Rezultati i diskusija}

U tablici 3 prikazan je prosječan stupanj preferencije glazbenih ulomaka. Učenici su najvišim ocjenama ocijenili skladbu W. A. Mozarta: Klavirska sonata u A-duru, $K V$ 331, 3. st., Alla turca, a najnižim skladbu $R$. Schumanna: Radostan seljak. 
Tablica 3. Prosječan stupanj preferencija glazbenih primjera

\begin{tabular}{|l|c|c|c|c|}
\hline \multicolumn{1}{|c|}{ Glazbeni primjer } & M & min. & max. & SD \\
\hline J. S. Bach: 2. Suita u h-molu, Badinerie & 4,07 & 1,00 & 5,00 & 1,05 \\
\hline J. Strauss: Pizzicato polka & 3,86 & 1,00 & 5,00 & 1,22 \\
\hline $\begin{array}{l}\text { P. I. Čajkovski: Koncert za klavir i orkestar br. } 1 \\
\text { u b-molu, op. 23, 1. stavak }\end{array}$ & 4,33 & 1,00 & 5,00 & 1,06 \\
\hline R. Schumann: Divlji jahač & 3,94 & 1,00 & 5,00 & 1,19 \\
\hline R. Schumann: Radostan seljak & 3,56 & 1,00 & 5,00 & 1,29 \\
\hline J. Brahms: Madarski ples u g-molu, br. 5 & 4,24 & 1,00 & 5,00 & 1,21 \\
\hline P. I. Čajkovski: Koračnica iz baleta Orašar & 4,20 & 1,00 & 5,00 & 1,17 \\
\hline G. Rossini: Wilhelm Tell, uvertira & 4,39 & 1,00 & 5,00 & 0,98 \\
\hline $\begin{array}{l}\text { W. A. Mozart: Klavirska sonata u A-duru, KV } \\
\text { 331, 3. st., Alla turca }\end{array}$ & 4,47 & 1,00 & 5,00 & 0,96 \\
\hline J. S. Bach: Toccata u d-molu, BWV 565 & 4,34 & 1,00 & 5,00 & 1,14 \\
\hline L. van Beethoven: Za Elizu & 4,40 & 1,00 & 5,00 & 1,12 \\
\hline E. Grieg: PeerGynt, Jutro & 4,39 & 1,00 & 5,00 & 1,18 \\
\hline
\end{tabular}

\section{H1: Mladi učenici, u odnosu na starije učenike, više preferiraju klasičnu glazbu.}

Da bi se istražio utjecaj dobi na učeničke preferencije klasične glazbe, izračunan je Mann-Whitneyev U-test. Rezultati potvrđuju da se glazbene preferencije mlađih i starijih učenika značajno razlikuju (tablica 4, slika 1). Mlađi učenici, u odnosu na one starije, više preferiraju klasičnu glazbu, čime je potvrđena postavljena hipoteza.

Takvi su rezultati ${ }^{20} \mathrm{u}$ skladu s rezultatima istraživanja ${ }^{21}$ koji potvrđuju da su mlađi učenici otvoreniji prema različitim glazbenim stilovima i prema glazbi koja im nije poznata. ${ }^{22}$

Tablica 4. Razlike u preferencijama klasične glazbe s obzirom na dob

\begin{tabular}{|c|c|c|c|c|}
\hline Glazbene preferencije & C & U & Z & P \\
\cline { 1 - 2 } mlađi učenici (2. i 3. razred) & 4,59 & \multirow{2}{*}{3765,00} & \multirow{2}{*}{6,93} & \multirow{2}{*}{0,000} \\
\hline stariji učenici (7.i 8. razred) & 4,00 & & & \\
\hline
\end{tabular}

$\backslash \mathrm{s}$

${ }^{20}$ Usp. David J. HARGREAVES, The development of aesthetic reactions to music, Psychology of Music, Special Issue, (1982) 51-54.

${ }^{21}$ Usp. Albert LEBLANC, Effect of maturation/aging on music listening preference. A review of the literature, izlaganja na 9. nacionalnom simpoziju o istraživanjima u muzičkom ponašanju, Oregon, Canon Beach, 7-9. ožujka 1991., Journal of Research in Music Education, 44 (1996) 1, 49-59.

${ }^{22}$ Usp. Albert LEBLANC i dr., Music style preferences of different-age listeners, Paper presented at the Tenth National Symposium on Research in Music Behaviour, Tusaloosa, Alabama, University of Alabama, 1993. U: International Journal of Psihology, Vol 43, Issue 3-4, 2008. 


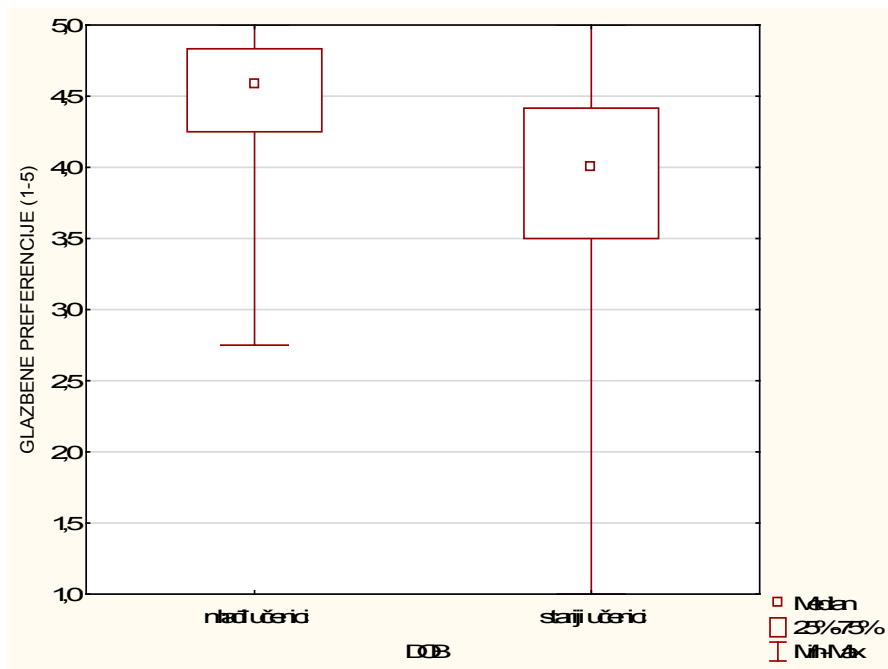

Slika 1. Razlike u preferencijama klasične glazbe s obzirom na dob

H2: Učenice, u odnosu na učenike, više preferiraju klasičnu glazbu.

Da bi se ispitao utjecaj spola na učeničke preferencije klasične glazbe, izračunan je Mann-Whitneyev U-test (tablica 5, slika 2). Rezultati ukazuju na razliku između učenika i učenica u preferencijama klasične glazbe, pri čemu učenice više preferiraju takvu glazbu. Time je potvrđena druga hipoteza.

Dobiveni rezultati u skladu su s rezultatima istraživanja ${ }^{23}$ kojima je potvrđeno da žene generalno imaju pozitivnije stavove prema glazbi i heterogeniji glazbeni ukus. ${ }^{24}$

Tablica 5. Razlike u preferencijama klasične glazbe s obzirom na spol

\begin{tabular}{|c|c|c|c|c|}
\hline Glazbene preferencije & $\mathbf{C}$ & $\mathbf{U}$ & $\mathbf{Z}$ & $\mathbf{P}$ \\
\cline { 1 - 2 } Učenici & 4,31 & \multirow{2}{*}{6448,00} & - & \multirow{2}{*}{0,021} \\
\hline Učenice & 4,50 & & 2,31 & \\
\hline
\end{tabular}

\footnotetext{
${ }^{23}$ Usp. Peter G. CHRISTENSON, Jordan B. PETERSON, Genre and gender in the structure of music preferences, Communication Research, 15 (1988) 3, 282-301.

${ }^{24}$ Usp. Anna C. HARRISON, Susan A. O'NEILL, Preferences and children's use of gender-stereotyped knowledge about musical instruments: Making judgements about other children's preferences, Sex Roles, 49 (2003) 7/8, 389-400.
} 


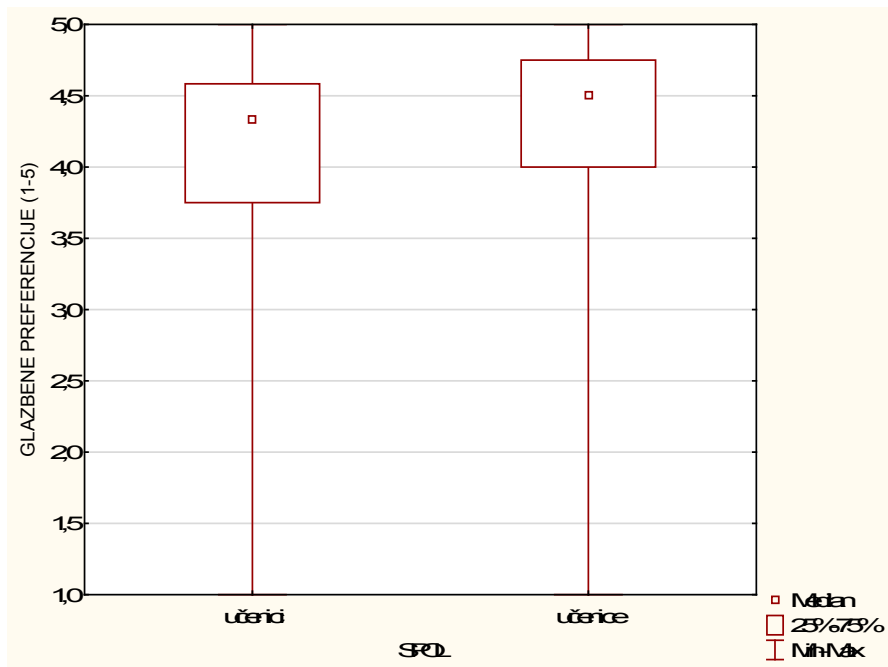

Slika 2. Razlike u preferencijama klasične glazbe s obzirom na spol

\section{H3: Učenici više preferiraju klasičnu glazbu u duru, nego u molu.}

Da bi se istražio utjecaj tonaliteta na učeničke preferencije klasične glazbe, izračunan je Wilcoxonov test parova (tablica 6, slika 3). Dobiveni rezultati ukazuju na to da učenici više vole klasičnu glazbu u molu, nego u duru, čime je odbačena postavljena hipoteza.

Takvi rezultati nisu u skladu s rezultatima istraživanja ${ }^{25}$ koja potvrđuju da sudionici generalno preferiraju glazbu u duru. ${ }^{26}$ Povezivanje tonaliteta s emocionalnim odgovorom na glazbu rezultat je usvajanja normi zapadnoeuropske glazbene tradicije. ${ }^{27}$

Tablica 6. Razlike u preferencijama klasične glazbe s obzirom na tonalitet

\begin{tabular}{|c|c|c|c|c|}
\hline Tonalitet & $\mathbf{C}$ & $\mathbf{T}$ & $\mathbf{Z}$ & $\mathbf{P}$ \\
\hline Dur & 4,33 & \multirow{2}{*}{7756,00} & 2,06 & \multirow{2}{*}{0,039} \\
\hline Mol & 4,50 & &
\end{tabular}

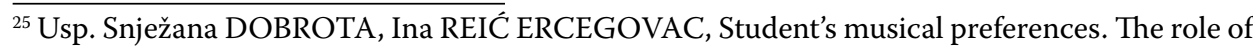
music education, characteristics of music and personality traits, Croatian Journal of Education, 16 (2014) 2, 363-384.

${ }^{26}$ Usp. Dobrota, Reić Ercegovac, The relationship between music preferences..., 236.

${ }^{27}$ Usp. Gregory, Worrall, Sarge, The development of emotional responses..., 347.
} 


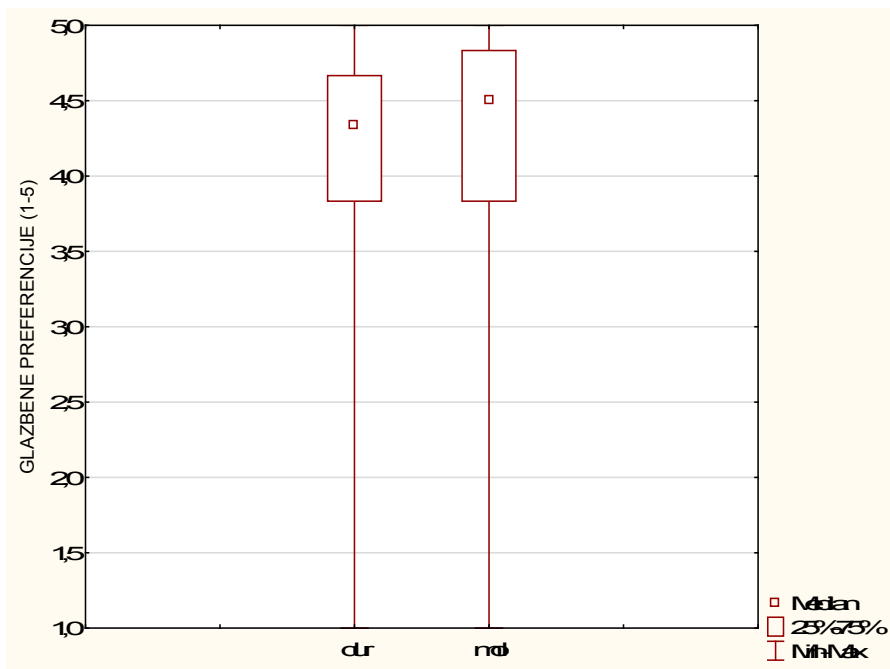

Slika 3. Razlike u preferencijama klasične glazbe s obzirom na tonalitet

\section{H4: Učenici više preferiraju poznatu klasičnu glazbu, u odnosu na klasičnu glazbu koja im nije poznata.}

Da bi se ispitao odnos između poznavanja glazbe i učeničkih preferencija klasične glazbe, izračunane su korelacije između poznatosti i glazbenih preferencija (tablica 7). Uočeno je postojanje takvih korelacija za sve glazbene primjere, čime je potvrđena posljednja hipoteza.

Dobiveni rezultati u skladu su s rezultatima brojnih istraživanja koja potvrđuju pozitivnu linearnu povezanost između frekvencije slušanja glazbe i glazbenih preferencija. ${ }^{28}$ Glazbeno-pedagoške implikacije dobivenih rezultata odnose se na potrebu višekratnog i aktivnog slušanja i izvođenja glazbe.

\footnotetext{
${ }^{28}$ Usp. Kenneth D. CARPER, The effects of repeated exposure and instructional activities on the least preferred of four culturally diverse musical styles with kindergarten and pre-k children, Bulletin of the Council for Research in Music Education, 151 (2001) 41-50; Dobrota, Reić Ercegovac, Music preferences with regard to music education..., 41-55; Leif FINNÄS, How can music preferences be modified? A research review, Bulletin of the Council for Research in $\mathrm{Mu}$ sic Education, 102 (1989) 1-58; Adrian C. NORTH, David J. HARGREAVES, The Social and Applied Psychology of Music, New York, Oxford University Press, 2008.
} 
Tablica 7. Povezanost između poznatosti glazbe i glazbenih preferencija

\begin{tabular}{|l|c|c|c|}
\hline \multicolumn{1}{|c|}{ Glazbeni primjer } & $\begin{array}{c}\text { Nepoznato } \\
\text { (f) }\end{array}$ & $\begin{array}{c}\text { Poznato } \\
\text { (f) }\end{array}$ & $\begin{array}{c}\text { Korelacija } \\
\text { između } \\
\text { sviđanja i } \\
\text { poznatosti }\end{array}$ \\
\hline J. S. Bach: 2. Suita u h-molu, Badinerie & 164 & 86 & $0,23^{*}$ \\
\hline J. Strauss: Pizzicato polka & 152 & 98 & $0,34^{*}$ \\
\hline $\begin{array}{l}\text { P. I. Čajkovski: Koncert za klavir i orkestar br. 1 u } \\
\text { b-molu, op. 23, 1. stavak }\end{array}$ & 137 & 113 & $0,22^{*}$ \\
\hline R. Schumann: Divlji jahač & 152 & 98 & $0,29^{*}$ \\
\hline R. Schumann: Radostan seljak & 152 & 98 & $0,19^{*}$ \\
\hline J. Brahms: Madarski ples u g-molu, br. 5 & 86 & 164 & $0,44^{*}$ \\
\hline P. I. Čajkovski: Koračnica iz baleta Orašar & 61 & 189 & $0,29^{*}$ \\
\hline G. Rossini: Wilhelm Tell, uvertira & 47 & 203 & $0,29^{*}$ \\
\hline $\begin{array}{l}\text { W. A. Mozart: Klavirska sonata u A-duru, KV 331, 3. } \\
\text { st., Alla turca }\end{array}$ & 35 & 215 & $0,22^{*}$ \\
\hline J. S. Bach: Toccata u d-molu, BWV 565 & 23 & 227 & $0,29^{*}$ \\
\hline L. van Beethoven: Za Elizu & 21 & 229 & $0,37^{*}$ \\
\hline E. Grieg: Peer Gynt, Jutro & 10 & 240 & $0,24^{*}$ \\
\hline
\end{tabular}
"p $<0,05$

\section{Zaključak}

$\mathrm{Na}$ temelju rezultata istraživanja, glazbene preferencije kao kratkoročne procjene sviđanja glazbenog djela, potvrđene su kao kontekstualno uvjetovane čimbenicima koje smo istraživali te smo utvrdili da je poznavanje glazbe značajan faktor koji utječe na glazbene preferencije. »Mlađi učenici bolje prihvaćaju različite i nepoznate glazbene stilove te pokazuju generalno veće preferencije svih stilova u odnosu na starije učenike. ${ }^{29}$ Otvorenost mlađih učenika prema nepoznatoj glazbi od velikog je značenja s obzirom na to da se stavovi prema glazbi formiraju u ranom djetinjstvu. Budući da su mlađi učenici otvoreniji prema različitim glazbenim stilovima, kao i prema glazbi koja im nije poznata, smatramo da se korištenjem kvalitetne klasične glazbe u programu predmeta Glazbena kultura, može izravno utjecati na glazbeni ukus učenika i kvalitetu njihova dugoročnoga glazbenog obrazovanja.

Rezultatima ovog istraživanja potvrđeno je da su dob i spol značajni prediktori preferencija klasične glazbe. Djevojčice, u odnosu na dječake te mlađi učenici u odnosu na starije učenike, više preferiraju klasičnu glazbu. S obzirom na to da naše istraživanje ukazuje na to da mlađi učenici pokazuju veće preferencije prema klasičnoj glazbi u odnosu na starije učenike, smatramo da ovaj rezultat istraživanja treba biti iskorišten kao argument za značajno veću zastu-

\footnotetext{
${ }^{29}$ Dobrota, Reić Ercegovac, Zašto volimo ono što slušamo?..., 20.
} 
pljenost klasične glazbe u razrednoj nastavi. Jako je zanimljiv rezultat istraživanja koji ukazuje na to da učenici više vole klasičnu glazbu u molu, nego u duru, jer on značajno odskače od rezultata dosadašnjih istraživanja ${ }^{30}$ koja tvrde da se općenito preferira glazba u duru. Ovo je, u svakom slučaju, neočekivan rezultat kojeg treba dodatno i detaljnije ispitati.

Ovo istraživanje rezultiralo je zanimljivim rezultatima iz kojih možemo uvidjeti potrebu kvalitetnijeg i kvantitativno zastupljenijeg programa glazbene kulture u osnovnim školama. Smatramo da su dobiveni rezultati istraživanja dodatno učvrstili postojanje izravne veze predmetnih čimbenika i njihova utjecaja na razvoj glazbenih preferencija, no podjednako je zanimljiva i hipoteza koja istraživanjem nije potvrđena. Važno je inzistirati, sukladno potrebi formiranja glazbenog ukusa kod osnovnoškolskih učenika i prema rezultatima ovog istraživanja, na višekratnom aktivnom slušanju i izvođenju klasične glazbe u nastavi Glazbene kulture. Budući da su mlađi učenici otvoreniji prema različitim glazbenim stilovima, kao i prema glazbi koja im nije poznata, upravo korištenjem kvalitetne klasične glazbe u programu predmeta Glazbena kultura u osnovnoškolskom programu, a nadasve u razrednoj nastavi, može se izravno utjecati na glazbeni ukus učenika i kvalitetu njihovog dugoročnog glazbenog obrazovanja. Na temelju dobivenih rezultata moguće je koncipirati program nastave Glazbene kulture koji bi bio u skladu s učeničkim preferencijama, a obuhvaćao bi suvremeniji pristup nastavi glazbe kroz konkretne metode poticanja intrinzične motivacije učenika. Na taj način bi se aktualizirala područja rada u nastavi Glazbene kulture te bi se moglo izbjeći stvaranje sudova starijih učenika orijentiranih prema javnom mnijenju, odnosno informacijama koje plasiraju mediji. Time bi zasigurno nastava glazbe učenicima bila zanimljivija i poticajnija te bi se ostvarivao njezin cilj u estetskom odgajanju učeniku.

\footnotetext{
${ }^{30}$ Usp. Dobrota, Reić Ercegovac, Student's musical preferences.., 380; Dobrota, Reić Ercegovac, The relationship between music preferences..., 239.
} 


\section{Daniela Petrušić* - Lidija Brkan*** \\ Students' Musical Preferences for Major and Minor Compositions \\ Summary}

The aim of this research was to explore students' music preferences for classical music, their music preferences of classical music in major and minor and the impact of familiarity on students' music preferences. The research was conducted in February 2019. As part of the research, a general data questionnaire and an assessment scale were used to examine the preferences of musical passages on a sample of 250 students attending the second, the third, the seventh and the eighth grade in elementary school. The results confirmed that the age and the gender are significant predictors of classical music preferences. Girls compared to boys and younger students compared to older students shows greater preferences for classical music. The obtained results indicate that students prefer more classical music in minor than in major. Finally, familiarity of music is a significant factor which effects on student's music preferences which is in accordance with numerous previous researches.

Key words: classical music, major, minor, music lessons, music preferences.

(na engl. prev. Daniela Petrušić)

\footnotetext{
* Daniela Petrušić, professor of music theory subjects, assistant, University of Split, Faculty of Philosophy, Department of Early and Preschool Education; Address: Poljička cesta 35, HR21000 Split, Croatia; E-mail: dpetrusic@ffst.hr.

**: Lidija Brkan, master of primar education, Address: Dinka Štambaka 7, HR-21260 Imotski, Croatia; E-mail: lidija.brkan@gmail.com.
} 